\title{
Framing and Experimentation in Economic Policy: The Case of the New Deal Agricultural Regulation
}

\author{
Ivan D. Trofimov \\ Department of Economics, Macquarie University \\ NSW 2109, Australia \\ Tel: 61-4-3767-9827Ｅ-mail: ivan.trofimov1@gmail.com
}

Received: August 25, 2011

Accepted: October 16, $2011 \quad$ Published: March 1, 2012

doi:10.5539/ass.v8n3p14

URL: http://dx.doi.org/10.5539/ass.v8n3p14

\begin{abstract}
The problems of sub-optimality and instability of the policy regime (agricultural policy regime in the USA in the $1920-1940$ s as a specific case) as well as the uneasy relationship between practical policy making and economic theory are examined from framing and experimentation perspectives. It is shown that policy formulation is an open-ended process (that eventuates in a unique configuration of mechanisms and underlying institutions), guided by political acceptability and social appropriateness logics, with stable policy outcomes critically dependent on the presence of the consensually held policy frames. Regarding optimality problem, a less restrictive procedural criterion to evaluate policies is advanced.
\end{abstract}

Keywords: Agricultural policy, New deal, Framing, Experimentation

\section{Introduction}

This paper examines the process of finding policy solutions to agricultural problems in the US over the period of the 1920-1940s (including F. D. Roosevelt's New Deal) and constructing stable agricultural policy regime.

This issue is worth investigating for two reasons. Firstly, as put by Nobel Laureate G. Stigler (1975), "Until we understand why our society adopts its policies, we will be poorly equipped to give useful advice on how to change these policies", i.e. understanding of policy formulation is a prerequisite for understanding of policy reform, as well as for devising new policies. In this connection, it is essential to assess whether US farm policies of the 1920-1940s were the right response to adverse developments that affected economic actors at the time, and whether they were the best response. Secondly, from policy theory viewpoint, it is necessary to establish the relationship between the stability and change in the policy system, explain why stable policies are not reached once and for all, and why economic malfunctions and inconsistencies that warrant policy innovation are not eliminated completely and require further policy action.

We answer four questions:

What were the pivotal factors (agential and ideational) that brought about the policy regime in a particular form and shape?

Were the policymaking efforts optimal and appropriate from both narrow economic and broader social and political perspectives?

What was the relationship between normative prescriptions of economic theory and practical policymaking? and

Was solid and stable policy regime attained?

The argument of the paper is that protectionist and interventionist regime that solidified in the USA was a specific response to the "farm problem" and economic and social conditions of the time. Brought into being through policy experimentation and search for suitable and appropriate (rather than optimal and perfect) solutions, it was also a product of conflicting policy ideas prevailing at the time of its formation. These factors determined its dual nature: on one hand the reforms of the New Deal had immediate success and solved most of the problems, associated with agricultural depression; on the other hand, it was less potent in advancing broader and deeper reforms and in establishing policies that would have smaller and fewer externalities and negative effects both in the US and overseas. 
Section 2 of the paper outlines the components and manifestations of the "farm problem" and reviews normative prescriptions to agricultural policymaking. It is shown that this normative approach is deficient as far as the persistence of sub-optimalities in actual policies is concerned and that it bypasses ideational and agency aspects of policymaking. An alternative framework remedying these shortcomings and based on the concepts of policy experimentation and framing is presented as an alternative. In Section 3 the path of policy experimentation during the New Deal period is examined and certain conclusions are made as to the nature and normative implication of policy experimentation. In Section 4 the ideational underpinnings of the New Deal agricultural regulation and the problem of instability of agricultural institutions are discussed. Section 5 provides conclusions regarding the New Deal agricultural policymaking.

\section{Theoretical aspects of agricultural policymaking}

The modern agricultural economics literature identifies three components of the "farm problem" that are typical to any agricultural economy in the process of industrialization (i.e. economy that is not purely subsistence and that has links to the urban industrial economy):

Low returns The growing incomes of city dwellers are not accompanied by a commensurate growth in food expenditure (Schultz, 1945). On the supply side, the technological treadmill tends to put average income of agricultural producers under pressure. The competitive nature of agricultural production (and consequently the inability of farmers to set prices) requires producers to undertake constant technological improvements in order to maintain their incomes and reduce costs. However, the technological rents are only available to the early adopters of technology. Others do not receive adequate returns from investment, but collectively contribute to the oversupply caused by new technologies. As a result of this competition between technology adopters, the average income across agricultural producers will always be under pressure with those unable to capture technological rents experiencing declining incomes (Cochrane, 1958). Thus, the combination of low income elasticity of food demand and the continuous technological innovation lead to an increase in agricultural output, deterioration of agricultural prices and agricultural-industrial terms of trade (Valdes, Zeitz, 1995).

Market instability The exposure of agricultural production to biological and climatic factors (supply variability), combined with high price and income inelasticity of demand and farmers' production decisions being made based on previous years' prices, lead to wide and unexpected price fluctuations - so-called unstable cobweb (Ezekiel, 1938).

Slow adjustment The relative oversupply of labour and its low transferability to other sectors, the low salvage value of capital assets, specific competitive market structure (price-taking, and inability to increase market share together with large proportion of fixed and sunk costs), as well as imperfect knowledge of the uncertainties of institutional, technological and physical environment - all mean that in the presence of adverse conditions (price fall), the farmers prefer to stay "on the land", minimise losses and sustain and/or expand output (Tweeten, 1971).

In order to tackle the problem the prescriptions of welfare economics on the choice of policies are unequivocal: the "first-best" solution is the introduction of structural policy, which (addresses the $3^{\text {rd }}$ component of the "farm problem". The structural policy includes measures to tackle the long-term deterioration of farm incomes and living standards as well as increase productivity through the promotion of technological innovation, building production capacity and the rationalization of the production factors and structure. This helps to reduce the number of farms and farm population, in particular by the means of early retirement schemes by increasing work opportunities for farmers outside agriculture and so on. This would automatically lead to the higher returns from farm production and higher incomes, thereby solving the $1^{\text {st }}$ and $2^{\text {nd }}$ component of the "farm problem".

The "second-best" option is the combination of income (addressing the $1^{\text {st }}$ component) and price support measures (addressing the $2^{\text {nd }}$ component). The selection of price support policy alone is seen as a suboptimal solution. The ranking is justified by historical reference: the sustained income and rural society improvements were attained in countries that facilitated structural change in agriculture earlier in their history (the UK, The Netherlands, and Denmark) and gave it priority over mere price and income support policies (Hallett, 1968). The reliance on the latter tends to delay improvements and productivity rise (higher and more generous supports lower the incentives of farmers to undertake structural change themselves and, in case of price supports, induce them to overproduce). The preference of income over price support is justified by its smaller distortions: the welfare losses induced by the former include taxpayers' losses, whereas the latter induces two losses due to more expensive domestic supplies and the reduction of cheaper import supplies.

Despite the parsimoniousness of this normative theory, subsequent sections of this paper demonstrate that the choice of regulatory solutions to the "farm problem" in the USA rarely followed economic prescriptions. Instead substantial recombination and experimentation with policy mechanisms took place, as well as contestation of 
ideas of how agricultural policy should look like.

We argue that in order to provide an adequate explanation of persisting sub-optimal regulation, the latter has to be conceptualized in terms of policy regime. As argued by Harris and Milkis (1996), policy regime is the constellation of policy institutions, defined as a set of ideas, consensually held by policy actors of what the social reality around them looks like and what the policy ought to be to conform to these ideas (Myrdal, 1944), and specific policy mechanisms and instruments. The stable policy regime is attained, when:

Ideational conflicts are eliminated or minimized by means of framing, and

Solid and internally consistent policy mechanism is created by means of experimentation.

Framing. Its function is to mould the "primeval soup" of ideas, views and blueprints spread across the policy system into an articulated argument (containing in itself the diagnosis of the policy problem as well as tentative solutions) that would be accepted by a sufficient number of policy actors (i.e. will become consensual institution) and that would direct and guide policymaking. This will ensure coherence of the policy system, which is indispensable both for the preservation of existing policy constructs and for policy innovation (Schon, Rein, 1994).

As policy system is pervaded by opposing ideas and frames, the attainment of a shared frame is not an unconflictual process, with actors attempting to push forward and impose their desired frame. While the form of framing will vary substantially depending on the policy setting and the degree of dissonance between existing and alternative frames, the essence of framing is a normative de-legitimisation of existing policy ideology and presentation of the latter as inappropriate in the eyes of society and unsuitable for solution of policy problems. The mechanics of framing is based on rhetorical actions and appeals to "follow the right way" and desist from currently held frames. Following Benford and Snow (2000) we argue that the success of framing rests on the resonance of the argument, determined by its consistency (clear cut interpretation of what is wrong and why it has to be tackled in a particular way) and credibility (frames not contradicting reality and not advanced solely for demagogical and politicking purposes).

Experimentation. Following Hall (1993) and May (1992), policy experimentation is defined as a deliberate attempt by actors to adjust policy mechanisms (instrument settings, choice of instruments) in response to adverse developments, affecting social and economic actors, failures in existing policies or new information about policy issues, thereby bringing in stable policies and removing inconsistencies in the policy system. Experimentation, being a trial-and-error exploration process is inevitable, because actors typically have limited comprehension of what the problems are that may justify policy adjustment and change, and due to the fact that problems do not find solutions easily and understanding of right solutions does not come instantaneously.

It is essential to explore the nature of experimentation process and its outcomes and to determine whether chosen experimentation path was socially optimal. In this respect two polar types of experimentation are distinguished:

It may be performed collectively through collaboration of government bureaucrats with other stakeholders, including policy recipients. Alternatively, it may be performed in coercive and non-democratic fashion, with resulting policies imposed on other actors (Wallis, 1997).

It may be performed in a pragmatic and flexible fashion, with policy mix and instruments chosen to satisfy specific needs of policy recipients and address specific pressing problems and with due recognition of the appropriateness of policy in light of objective constraints and political and social context. Alternatively, it may be undertaken in a dogmatic fashion in order to deliver policies that would satisfy some ex ante chosen criterions and objectives with no consideration of policy suitability (Tool, 1995).

In sections 3 and 4 we examine which experimentation type agricultural policymaking in the 1920-1930s conformed to and what the nature of policy framing was.

\section{Agricultural policy experimentation}

In the context of agricultural depression of the 1920-1930s (and the fall in commodity process that accompanied it) and during the establishment of the new farm policies during the New Deal, policy experimentation involved weeding out solutions that were either unfeasible in the farm sector or did not work; as well as adoption of solutions that seemed appropriate in the existing political and economic climate, but did not necessarily reflect the best available social and economic knowledge on the "farm problem".

Firstly, the most obvious solution to low returns, excess capacity and slow adjustment that has been used to cure industrial sector problems during depressions was not viable in agricultural sector. The formation of the recession cartel, the agreement by firms of a specific industry to cooperatively reduce production capacity in 
order to lift prices when the industry is in decline (Note 1), would not be possible (had agricultural policymakers of the 1920s decided to take this measure) - individual producers were too small and numerous and the costs associated with forming and enforcing a cartel were high.

Secondly, the mechanism to coordinate producers' efforts by supporting agricultural cooperatives and associations failed. Initially the formation of agricultural corporatist and cooperative arrangements was encouraged to provide assistance and political support in implementation of government programs, to rationalise production and marketing and to provide decentralised institutions beneficial for the rise of commercial agriculture the (period prior to World War I). In the 1920s, the government tried to enlist agricultural cooperatives in the attempt to stabilise prices. In the USA, W. Jardine in the Coolidge Administration and later President Hoover insisted that the establishment of farmer controlled marketing cooperatives and the cooperation of the latter with policymakers would regulate the supply of commodities to markets and smooth price fluctuations, thereby bringing the depression to an end (Hoover, 1929). The success of this associationalist regulation depends crucially on the incentives of both bureaucrats and producers to establish policy partnerships, and the ability of farm associations to achieve comprehensiveness of membership and a sound position in the decision-making system (preventing at the same time free-riding behaviour of members). The failure of producers to foster cooperation in the American Farm Bureau Federation in the 1920s and the impotence of the Federal Farm Board to direct and oversee farm cooperatives during the Great Depression show that this task was not attainable (Note 2). Collaborative attempts to build nationwide cooperatives and to shift market power away from intermediaries failed; the bureaucratic management and forcing of decisions upon cooperatives diverted the support of the latter (Sheingate, 2001). Overall, the failure of institutional experiments of the 1920s made it clear to policymakers that prospective regulation of agricultural markets had to tackle the core problem of the sectoroverproduction - and to impose control on production, rather than rely solely on distribution and marketing regulation. In addition, it became apparent that greater experimentation was required to devise more sophisticated, workable and incentive providing instruments.

The policy decisions made by Roosevelt Administration in the 1930s were to remedy these earlier failures and to tackle persisting problems on the production side. Associationalism was rejected; however, a priority was given to price supports over structural policy (evaluated post factum, this policy choice is clearly at odds with economic theory prescriptions). The unstable cobweb implied clear justification for price regulation: Ezekiel (1933) asserted that price instability was leading to permanent price risks for farmers and these risks were large enough to jeopardise agricultural growth and development. Hence, a large efficiency gain was expected from direct administration of agricultural prices. The New Deal farm legislation embodied several measures to support prices, not rejecting their direct administration and setting. In addition, mechanisms not limited to price support were introduced (e.g. measures to foster scientific research and extension, crop insurance, subsidization of food distribution, conservation of land etc). As put by Breimyer (1983), "the New Deal was to attack many problems simultaneously and by a variety of means".

While the debates on the scope and depth of government involvement in price setting and on the use of other instruments were present through the 1930s, overall the Roosevelt Administration did not stick to one particular instrument or deal with single problematic area, but preferred a pragmatic approach, trying several policy avenues, including issues not restricted to farmers' incomes and prices and being ready to make modifications to policy choices. Some instruments were rejected for example, payments to farmers in distress, which were considered to be humiliating handouts. At the same time, some earlier proposals were viewed favourably - the McNary-Haugen plan to raise domestic prices, the idea of G. Peek and H. S. Johnson of ensuring pre-war parity prices, Secretary H. C. Wallace's proposal of adequate tariff protection, as well as widespread ideas of surplus disposal overseas (Halcrow, 1983: 88-92). In a similarly pragmatic fashion, the "domestic allotment plan" (Note 3 ), the cornerstone of the New Deal and subsequent farm legislation, was complemented by other instruments. As production control took time to deliver results and supply on many occasions was too large, the Commodity Credit Corporation (CCC) was instituted to deliver more immediate stabilisation of markets (Note 4). The designers of the CCC remembered the dismal experience of the Federal Farm Board and hence were eager to ensure higher effectiveness of stabilisation: as a matter of experiment, new features (loan differentials) were introduced to address grade and location specifics of the farm economy. In the case of grades this proved workable (Shepherd, 1942). However, the attempts to tinker with loan rates to increase prices well above market clearing level were not successful, with stabilisation stocks and CCC financial losses growing to threatening levels (Note 5). Another improvisation was a tie-in of the CCC with parity prices. It became apparent that the latter important instrument was not included in any New Deal program. Hence, under pressure of organised interests, in 1938 the CCC was ordained with an unusual feature - a new instrument, the "price support loan", 
combining the existing CCC loan rate with "price parity". Following that, the rates of a newly established loan started to be pushed further upwards, in accordance with the parity formula, reaching $90 \%$ during the war.

Also, the difficulties in building farmers' cooperation in the 1920s pushed New Deal designers to try marketing orders as an instrument to overcome incentive problems when members of voluntary cartel undercut other members and expand production. The Agricultural Marketing Act of 1937 authorised USDA to run referenda among producers at their request and to appoint the panel of producers and processors to make marketing decisions in the interest of all parties. The $2 / 3$ "yes" vote, however, obliged all members to comply with marketing orders, thereby preventing usual free-riding in cartels. This was clearly a remedy against the cooperative failures of the $1920 \mathrm{~s}$.

Finally, as an addition to core New Deal programs, the Resettlement Administration was founded to cover those not included in the New Deal and to help those farm communities in locationally and economically disadvantaged areas to make a new start in more productive areas.

Overall, working and consistent regulatory system, composed of interrelated and mutually supporting elements, was gradually created.

Today it is common among agricultural economists to identify ex post the shortcomings and flaws of the New Deal legislation and to claim that choices made were an error from the very start. An example of these assertions is the meticulous analysis of faulty New Deal design by Pasour (1990). From an economic point of view, Pasour states that the New Deal programs:

Decreased allocative efficiency and social welfare. The implementation of the allotment plan resulted in increasing production costs and inefficient substitution of other inputs for land. Hence, production controls had to be extended further and further and also be supplemented by marketing quotas;

Produced unintended consequences that had to be remedied through additional programs, bureaucratic and administrative expansion and conflict resolution. Specifically, the accumulation of surpluses required further unplanned policies, such as land diversion to conservation (under the Soil Bank program of 1956), surplus disposal in international markets (creating trade tensions), the creation of food aid programs (which in their turn, due to their irregularity and ad hoc nature, created disruptions in Third World agricultural economies); and

Compromised liberties and freedoms, and were in uneasy relations with the law. In particular, marketing orders, as government sponsored cartels, conflicted with anti-trust law (and thereby were illegal) with government making no moves to treat agricultural restrictive practices in the same way as practices in other industries. As to administration of production controls and marketing orders, pseudo-democratic referenda did not include taxpayers and consumers, i.e. those who ultimately beared the costs of farm programs.

Regarding negative implications for efficiency, we disagree with the critique by Pasour and posit that in the context of the 1930s (with skyrocketing unemployment, threat of famine, disruption of usual rural life and radicalisation of society) and in search for solutions that would work, the selection of the above-mentioned unique constellation of policies and instruments was the only realistic and practical response. The "narrow" efficiency criterion of policymaking does not take into account the broader social, political and economic repercussions and costs of not adopting seemingly suboptimal New Deal regulation. Additionally, it may be argued that no elaborated normative economic theory prescriptions were available for the New Deal policymakers in the 1930s with most progress in economic science made afterwards (i.e. in 1940-50s). Thus, on theoretical side a more holistic and historically prudent criterion should be used to evaluate the "true" effects of policy experimentation. In terms of practical policymaking, it is evident that the dominant logic of the New Deal was of acceptability and workability of policies. In hindsight it is impossible to establish whether an alternative logic of efficiency would have prevailed or delivered better policies in the context of the 1930s.

Likewise, regarding long-term unplanned consequences of the New Deal, the pragmatic experimentation that was performed did not require policymakers to be "hyper-planners" able to project far into the future and construct policies that would be appropriate once and for all. Indeed, as the very nature of pragmatic experimentation is to solve current problems, rather than problems that may emerge in the future (Tool, 1995), the outcomes and optimality of such experimentation should be evaluated respectively, from similar temporal perspective. New Deal policies were designed to address specific challenges of the time, were clearly successful in this regard, and were always thought to be subject to subsequent reform once circumstances change (Breimyer argues that New Deal was perceived as "emergency relief", "temporary", and a measure "for a season").

As to the alleged coercive nature of the New Deal, Breimyer, based on his participation in 1930s policymaking, adamantly rejects this claim, stating that New Deal policies were not imposed by Roosevelt and his inner 
decision-making circle upon the broad farm community. Firstly, such policymakers as M. L. Wilson were heavily involved in solving the "farm problem" at a state level; proposed policies followed directly from collective attempts of local decision makers and farmers to tackle challenges brought by depression. Indeed, the idea of acreage reduction and domestic allotment was born locally (on Lone Warrior Farm in Montana). Here cost-cutting attempts by Wilson and his associates forced them to conclude that with prevailing market prices for wheat, any further cuts would not bring positive profits. Hence, the production cuts were seen as the only solution to depression (Huffman, 1959). Secondly, by pressuring for policy change, the farmers (together with government) became co-creators of the New Deal. Thirdly, it rested on farmers' consent and approval: acreage reductions and marketing orders in all cases received a "yes" vote from farmers. Indeed, the New Deal may be seen as an exercise in direct democracy and as a manifestation of collective entrepreneurship by many actors.

\section{Competing frames and formation of consensual institutions}

We argue that despite successful policy experimentation, the 1930-1940s witnessed the lacking consensual institutions and the presence of ideational conflicts and dissonance. Compared to two earlier periods when consensual institutions (based on "official" and "rational" agrarianism) were attained, in this period a greater range of ideas and alternative frames were swarming into the policy system. Despite substantial adherence of the farm sector to F. D. Roosevelt's New Deal policies and to the underpinning ideas, counter-framing by actors both from the right and from the left continued throughout the 1930s and prevented New Deal frames from crystallising and gaining dominance. The erosion of New Deal legislation and agricultural policy regime instability were a result of these developments.

Different versions of agrarianism ("official", "popular", Progressivist/"rational" and in the 1940s "new"), as well as socialist and libertarian ideas, and later in the 1940s normative neoclassical economics interpretations of the agricultural sector - were the basis of framing, which was performed by various policymakers, economists and community movements.

As old as human civilization, agrarianism dates back to Greek and Roman philosophy, has been the core of teachings of the Catholic Church (family farm as cornerstone of moral health of society and as provider of food for humanity), the economic theory of Physiocrats (agriculture as principal productive activity in society), and the political views of Thomas Jefferson (the view that agrarian society is essential for functioning and viable democracy and preservation of liberties). In the early $20^{\text {th }}$ century, agrarianism became the centrepiece of "anti-modernism" and back-to-the-land social movement (Montmarquet, 1989).

The version of agrarianism that had been embodied in US farm policy since A. Lincoln and that formed the ideational "official" consensus between policymakers and economists saw the US farmland dominated by independent land-hungry settlers operating their family farms, relying on their own against a hostile environment with few resources except for their own labour. Together with the objective pressure to populate vast lands, this agrarian ideal envisaged supportive, albeit non-interventionist, policy, aiming to encourage and ease the access to land, to merely provide economic opportunity. In line with this vision, the later policies targeted to encourage the development of capitalist agriculture - the system of land grant colleges, promoting technological transfer into the farm system, served this purpose. Welfare support and social security functions, as well as the extent of regulation were limited, with the USDA serving educational, scientific and statistical functions.

The Progressive Era (coinciding with presidential terms of T. Roosevelt, W. H. Taft and W. Wilson) brought a social agenda into the policy system: the Country Life Commission, appointed by President T. Roosevelt tackled a broad spectrum of problems in rural America - the quality of rural education, soil erosion, an unjust tax system and land speculation, poor work conditions, rudimentary health conditions and others (Ellsworth, 1960). The willingness of policymakers to solve pressing social problems indicates the powerful influence from the grassroots on "official" policy, with the stance of policymakers enriched by new ideas from the fringe of the policy system. Although many of the popular views on how to deal with excesses of agricultural capitalist development and mounting problems included outright rejection of technocratic, industrial, urban society (romantic agrarians, see Danbom, 1991), and populist attacks on middlemen by The Grange (association, representing small farmers), and hence were not incorporated into the newly emerging consensus, the Progressive Era marked the start of a metamorphosis of agrarianism towards more rational positivist responses to countryside problems. In the 1920-1930s, specifically during presidencies of Hoover and Roosevelt, these responses became prominent in the agricultural policy system.

H. Hoover, who in contrast to earlier Presidents, devoted a considerable amount of time to agricultural issues, had higher order goals beyond the task of assisting the farm sector. Hoover's political agenda envisaged the advancement of "American individualism" (Williams, 1972), at the core of which stood the voluntary 
cooperation of labour and capital to solve distributional and equity problems, improvement of marketing and production efficiency in the economic system as a whole and decentralisation of policy making. The measures, mentioned in the previous section (marketing cooperatives and the Federal Farm Board to organise and integrate them) served this broader objective well.

Concerning the motivations of F. D. Roosevelt, several authors (Frisch, 1963; Conrad, 1965) stress that he hardly had any far-reaching reformist agenda. Instead, as argued by Frisch, his main preoccupation was to preserve democratic order and prevent its depletion to the point where fascist and communist forces would come to the forefront of politics. The political discourse of the 1920s-1930s was not short of very radical ideas, including the proposals for revolution that Communists were making in the Midwest, the civil disobedience movements (Farmers' Holiday Movement of M. Reno) and demagogical proposals of production cost guarantees and debt moratoriums (Shover, 1965). The purpose of Roosevelt in this respect was to arrest these developments and prevent them from entering Washington politics. Frisch and Conrad similarly indicate an expressed conservative nature of Roosevelt's frames - the changes that were made in the first years of the New Deal were cut short and proponents of further action were pushed to resign.

Regarding the substance of both Presidents' frames and actual framing activities, neither of them disagreed with the consensual views that had been forming since the Progressive Era and had solidified in the 1920s. These views included:

That the difficulties of the farm sector followed from growing contradictions between production forces (continuing industrialisation of agriculture) and production relations and structure (family farms subordinated to other actors in the production system and dependent on forces beyond their control and thereby vulnerable to economic havoc and perturbations);

That agriculture, being a part of the interdependent economy, should receive adequate assistance and thereby contributes to economic development (to economic recovery in the 1930s) - the catch up of rural standards of living with urban ones leading to an increase of rural purchasing power; and

That to achieve the above task, agriculture is to be treated in rational and pragmatic terms, with farmers and their alleged virtuous character being "desacralised" and considered as ordinary businesspersons and labourers (Anderson, 1961).

Thus, the content of their frames (diagnosis of the problem and implied solution) were quite well rooted in the dominant Progressivist thinking, did not contradict it and were subscribed to by the broader policy community and general public rather eagerly. Indeed, it may be argued that no judicious framing or counter-framing efforts were required - there was no object of delegitimisation as the pro-change Progressivist agenda had long been installed (Note 6). Overall, we conclude that despite the presence of entrepreneurial and reformist motivations and leadership activities (by Hoover), no significant new and alternative frames were introduced by either top policymaker.

In contrast, substantial framing was performed by lower level actors - specifically political economists, who found their way into the Agricultural Adjustment Administration (AAA), USDA and Roosevelt's "Brain Trust" (Kirkendall, 1962). Both groups, the Midwestern "agrarian" and urban "liberal" factions (Note 7), while agreeing in principle with the above mentioned Progressivist consensus, were, being firm believers in deep and all-encompassing social reform, in other respects willing to modify and challenge it (as shown below).

The principal features of economic policy philosophy, subscribed to by the "agrarian" faction were:

The contention that Christian principles could be instrumental in social reform (based on their admiration of the Social Gospel movement of the early $20^{\text {th }}$ century);

The subscription to radical reformism, based on their exposure through university studies to profound critiques of the wastefulness and parasitism of the capitalist economy by T. Veblen. This radicalism, however, was positive and policy-oriented, due to the influence of J. R. Commons, the theorist of institutionalism, who was also a practical policymaker in Wisconsin;

The adherence to John Dewey's pragmatic philosophy, which encouraged openness to different ideas (frequently those from the radical left) and inspired ongoing non-dogmatic experimentation with policies; and

The view of the "farm problem" not as purely economic, but as social, manifested in the breadth of New Deal programs, and in the holistic research activity of the short-lived Bureau of Agricultural Economics (BAE), starting research in the new fields of rural sociology, agricultural history, and rural development.

The economic philosophy of the "liberals" was influenced by the ideas of scientific management and 
comprehensive planning that were popular in the 1910s-1920s. They also tended to emphasise the class aspect of social and economic problems in America (hence their disgust with "poverty amidst plenty"), and had faith in high quality public service, being genuinely interested in doing "good" for people.

It is clear that common ground with respect to the core foundations of new policies between the two groups was easily found. It envisaged:

Social orientation of proposed policies (Wallace, 1944);

A high degree of comprehensiveness and depth of regulation. It was consensually held that comprehensive "agricultural social engineering" should take place and that New Deal should not stop at instituting production controls, but should go further, establishing a comprehensive, scientifically planned system of US land resources management and profit regulation in the interest of all commercial producers, as well as consumers (Pasour, 2004: 108),

Enforcement of policies by pragmatic policymakers, insulated from vested interests and acting in the public interest (Note 8)

The attempt to translate these radical ideas into policy encountered vociferous opposition. Undoubtedly, as mentioned above, farmers generally supported the New Deal. So did the majority of the Congress. The Southern States, always suspicious about attempts of Washington to diminish states' powers and sticking to Jeffersonian ideals, turned pragmatic in the conditions of economic distress. Blocking with Midwest states ("marriage of cotton and corn"), they created a powerful support for the New Dealers (Schapsmeier, Schapsmeier, 1979: 353-354). Despite this, there were limits to support when it came to core beliefs and views. Several framers and policymakers, such as H. A. Wallace and R. G. Tugwell accentuated that the "farm problem" was one of the components of a broader "social problem" that included perverse labour and racial relations (that were particularly noticeable in the South). Consequently, the New Deal was seen as only a first step that had to be followed by more expansive and encompassing measures. Such framing was considered neither a credible, nor a legitimate interpretation of reality by various actors in the South with vested interests in continuing segregation and preservation of the sharecropping system.

The frames of New Deal radicals were also challenged from the right - by conservative factions of the Republican Party (particularly after 1938, when Republicans gained control over the Congress), American Farm Bureau Federation (AFBF), Liberty League and the National Committee to Uphold Constitutional Government. The following complementary frames that these actors considered consistent and credible can be distinguished:

The problem of rural poverty and destitution is a result of incompetence and indolence, the latter stemming from the lack of ownership. The problem can be solved, if the farmer is turned from tenant into land owner and thereby into an effective producer. Other policies (e.g. those envisaged by the Resettlement Administration) were deemed unnecessary. Thus, a clear clash of frames was present. New Dealers saw poor farmers as victims of forces beyond their control such as soil erosion and Dust Bowl, making it impossible to subsist on land. Education in farm management combined with resettlement into better production areas and a new start assisted by government planners and extension economists was therefore seen by New Dealers as a prerequisite for farm sustainability; hence, this lead to improvement of living standards of the rural disadvantaged. In contrast, conservatives, subscribing to the "old" agrarian ideal of independent yeomen, continued to believe that mere possession of land (without other improvements) is a guarantee of efficiency and adaptability and that it can prevent bankruptcy and foreclosures in difficult times. Tugwell (1959: 161) criticized this "American prejudice".

The problems of the farm sector are better comprehended by farm producers and are limited to failures in production and marketing. Any side measures (land retirement and conservation, drought-relief loans, subsidiary medical services and constructive/integral rural development) are considered neither relevant nor decisive, but rather hare-brained projects of city intellectuals.

Relief to the farm sector may be needed, but it should not hinder the normal course of production and rural life any attempts to structurally change the farm economy (e.g. through relocation of the labour force) is unnatural and limits freedom of all participants in rural relations.

Relief to the farm sector, even if successful, leads to problems of a much larger magnitude - to undesirable aggrandizement of offices and bureaucracy and potentially unrestrained power of politicians, which, if coupled with popular support of their programs, leads to elimination of opposing views, "democratic despotism" and thereby to totalitarianism and destruction of constitutional order (Rippa, 1965).

The New Dealers' frames continued to be challenged and counter-framed in the 1940s. While not denouncing the price policy in principle, the academic community suggested seeing farm sector problems from a broader 
perspective (Journal of Farm Economics, 1945). Firstly, the economists emphasised that agricultural intervention was proceeding in the name of improving living standards; yet little was known about the distribution of incomes before and after intervention. Secondly, they suggested that policy formulation should not rest solely on improvements on the production side, but also on the consumption side. Thirdly, they urged consideration of the structural measures, which was in many respects in line with the New Deal spirit (especially when it came to soil conservation, education and infrastructural services). These economists' interpretations of farm sector problems (particularly the first one, concerning income inequality) had a certain resonance and influenced the ill-fated post-war Brannan plan (Bradley, 1995: 248). The latter at the same time carried features of New Deal radicalism (due to C. F. Brannan's work in the Resettlement Administration), urging a "Fair Deal" to small family farming (Note 9). As with New Deal, the frame was counteracted from the right (indicating incompatibility of the redistribution ideology of the plan with freedom of entrepreneurship and of business decision-making), but also from the left (stating that the "Fair Deal" frame compromises the old agrarian ideal of independent and self reliant farmers).

\section{Conclusion}

Four insights can be inferred from the foregoing discussion.

Firstly, New Deal agricultural policy formulation was an open-ended process, with policy outcomes resulting from a specific coalescence of framing and experimentation efforts. The variations in these two activities would have eventuated in a policy of different form and content.

Secondly, what seems (in light of contemporary economic theory and in terms of discovered unplanned policy effects) to be a suboptimal policymaking, may in fact be a perfect and appropriate policy response, if it is evaluated from procedural optimality perspective (i.e. whether it is conducted democratically and pragmatically) rather than seen through teleological lens (e.g. evaluated against some "desirable" outcomes or imposed normative criteria). In this connection, New Deal policies can be considered suboptimal in narrow economic sense, while New Deal policy process may be seen optimal in procedural sense.

Thirdly, as illustrated by the New Deal episode, the relationship between the state of economic knowledge and policy practice is tenuous. The phenomenon of non-adherence to normative economic principles is explained not solely by the absence of such principles or policymakers' ignorance, but rather by the very nature of policymaking that is underpinned by political and social palatability of policy ideas and initiatives. It may be argued that even if New Dealers were fully cognizant of economic flaws in their policies, this may not have changed the direction and content of their policymaking efforts.

Fourthly, regarding stability of the policy regime and the room for ongoing policy innovation, we showed that neither of these is feasible in the absence of consensually held frames and solid policy institutions. Following judicious policy experimentation during the New Deal, major economic problems, stemming from the lack of regulation, were solved and working policy mechanism was established. However, further innovation (broadening and deepening of the New Deal) or preservation of already existing policy constructs were not possible, due to the active counter-framing by the conservative side of politics and to a much smaller extend by agricultural economics profession. The success of this counter-framing was facilitated by the perceived illegitimacy of the original New Deal frames that were seen as too radical, and by the objective diversity, flux and complexity of problems in the US farm economy that could not be diagnosed and dealt with by a single frame. Thus, many of the existing New Deal mechanisms were dismantled and many reformist and social improvement ideas were lost to public policy (the closure of the Bureau of Agricultural Economics, that was designed to be a coordinating organ for Resettlement Administration and for full-scale social reform of American agriculture, is a prime example). Overall, effective framing, bringing in consistent and credible frames that can withstand counter-framing attempts is indispensable for both policy regime stability and policy innovation.

\section{References}

(1945). Price policy for agriculture contest. Journal of Farm Economics, Vol. 28, No. 4.

Anderson, C. B. (1961). The metamorphosis of American agrarian idealism in the 1920s and 1930s. Agricultural History, Vol. 35, No. 4, pp. 182-188.

Benford, R. D. \& Snow, D. A. (2000). Framing processes and social movements: an overview and assessment. American Journal of Sociology, 26, pp. 611-633.

Bradley, K. J. (1995). Agrarian ideology and agricultural policy: California Grangers and the post-World War II farm policy debate. Agricultural History, Vol. 69, No. 2.

Breimyer, H. F. (1983). Conceptualization and climate for New Deal farm laws of the 1930s. American Journal of Agricultural Economics, Vol. 65, No. 5, p. 1153. http://dx.doi.org/10.2307/1240439

Cochrane, W. W. (1958). Farm prices - myth and reality. St. Paul: University of Minnesota Press. 
Conrad, D. E. (1965). The forgotten farmers: the story of sharecroppers and the New Deal. Urbana: University of Illinois Press.

Danbom, D. B. (1991). Romantic agrarianism in twentieth-century America. Agricultural History, Vol. 65, No. 4, pp. 1-12.

Ellsworth, C. S. (1960). Theodore Roosevelt's Country Life Commission. Agricultural History, Vol. 34, No. 4, pp. 155-172.

Ezekiel, M. \& Bean, L. H. (1933). Economic bases for Agricultural Adjustment Act. Washington: USDA.

Ezekiel, M. (1938). The cobweb theorem. Quarterly Journal of Economics, 53, pp. 255-280. http://dx.doi.org/10.2307/1881734

Fausold, M. L. (1977). President Hoover's Farm Policies 1929-1933. Agricultural History, Vol. 51, No. 2, pp. 362-377.

Frisch, M. J. (1963). Roosevelt the conservator: a rejoinder to Hofstadter. Journal of Politics, 25, p. 369. http://dx.doi.org/10.2307/2127470

Gilbert, J. (2000). Eastern urban liberals and midwestern agrarian intellectuals: two group portraits of progressives in the New Deal Department of Agriculture. Agricultural History, Vol. 74, No. 2, pp. 162-180.

Halcrow, H. F. (1983). Agricultural policy analysis. New York: McGraw-Hill, pp. 88-92.

Hall, P. (1993). Policy paradigms, social learning and the state. Comparative Politics, April, pp. 275-296. http://dx.doi.org/10.2307/422246

Hallett, G. (1968). The economics of agricultural policy. New York: Augustus M. Kelley, pp. 21-23, 24-27.

Harris, R. A. \& Milkis, S. M. (1996). The politics of regulatory change: a tale of two agencies. New York: Oxford University Press.

Hoover, H. (1974). Message to the special session of the Congress on farm relief, tariff and certain emergency measures, April 16, 1929. Public papers of the Presidents of the United States, Herbert Hoover. Washington: US Government Publication Office.

Huffman, R. E. (1959). Montana's contribution to New Deal farm policy. Agricultural History, Vol. 33, No. 4, p. 165.

Kirkendall, R. S. (1962). Franklin D. Roosevelt and the service intellectual. The Mississippi Valley Historical Review, Vol. 49, No. 3, pp. 456-471. http://dx.doi.org/10.2307/1902565

May, P. J. (1992). Policy learning and failure. Journal of Public Policy, 12(4), pp. 331-354. http://dx.doi.org/10.1017/S0143814X00005602

Montmarquet, J. A. (1989). The idea of agrarianism: from hunter-gatherer to agrarian radical in western culture. Moscow: University of Idaho Press.

Myrdal, G. (1944). An American dilemma. New York: Harper.

Pasour, E. C. (1990). Agriculture and the state. market processes and bureaucracy. New York: Holmes and Meier, p. 97.

Pasour, E. C. (2004). Agricultural economists and the state. Econ Journal Watch, Vol. 1, No. 1.

Rippa, S. A. (1965). Constitutionalism: political defence of the business community during the New Deal period. Social Studies, 56(5), pp. 187-190.

Schapsmeier, E. L. \& Schapsmeier, F. H. (1979). Farm policy from FDR to Eisenhower: southern democrats and the politics of agriculture. Agricultural History, Vol. 53, No. 1.

Schon, D. \& Rein, M. (1994). Frame reflection: toward the resolution of intractable policy controversies. New York: Basic Books.

Schultz, T. W. (1945). Agriculture in an unstable economy. New York: McGraw-Hill Book Company.

Sheingate, A. D. (2001). The rise of the agricultural welfare state: institutions and interest group power in the United States, France, and Japan. Princeton: Princeton University Press, pp. 99-107.

Shepherd, G. (1942). Stabilization operations of the Commodity Credit Corporation. Journal of Farm Economics, Vol. 24, No. 3, pp. 601-608. http://dx.doi.org/10.2307/1231966

Shover, J. L. (1965). Cornbelt rebellion: the Farmers' Holiday Association. Urbana: University of Illinois Press.

Stigler, G. J. (1975). The citizen and the state: essays on regulation. Chicago: University of Chicago Press, p. xi. 
Summers, M. (2000). The New Deal farm programs: looking for reconstruction in American agriculture. Agricultural History, Vol. 74, No. 2.

Tool, M. R. (1995). Pricing, valuation and systems. Essays in neoinstitutional economics. Aldershot: Edward Elgar.

Tugwell, R. G. (1959). The resettlement idea. Agricultural History, Vol. 33, No. 4.

Tweeten, L. (1971). Foundations of farm policy. Lincoln: University of Nebraska Press.

Valdes, A. \& Zeitz, J. (1995). Distortions in world food markets in the wake of GATT: evidence and policy implications. World Development, 23(6), pp. 913-926. http://dx.doi.org/10.1016/0305-750X(95)00023-6

Wallace, H. A. (1944). Democracy reborn, selected public papers. New York: Reynal and Hitchcock.

Wallis, J. (1997). Conspiracy and the policy process: a case study of the New Zealand experiment. Journal of Public Policy, 17(1), pp. 1-29. http://dx.doi.org/10.1017/S0143814X0000341X

Williams, W. A. (1972). What this country needs... some presidents, From Wilson to Nixon. New York: Review Books.

Notes

Note 1. The formation of the recession cartels becomes necessary in the case when industry/sector (particularly capital-intensive one, such as agriculture or heavy industry) has to undertake adjustment and restructuring due to the loss of competitiveness or inability to rationalise its capital assets. The task of the cartel is then to minimize the costs of adjustment.

Note 2. The second target of the Federal Farm Board (the removal of excess surplus) was similarly beyond reach - with the start of the Great Depression, the commodity prices fell further and by 1931, the Board experienced huge losses and spent all $\$ 500$ million of its initial endowment.

Note 3. Under the plan, the national allotment was set at a level that would meet anticipated domestic and export consumption. The individual allotments were then set based on historical plantings of the crop. See Pasour (1990).

Note 4. The CCC operated through both direct government purchases and a system of non-recourse loans. The loans were provided to farmers on a condition of removing the commodity from the market (placing it in government or farmer's own storage) and leaving it as collateral. The farmer had the opportunity to repay the loan with cash (if market prices are high enough to make sale of the stored commodity attractive) or (if prices are low) default on the loan and lose the collateral. The non-recourse nature of the loan meant that government had no means to force farmers to act in either way.

Note 5. The reason for setting loan rates at unjustifiable levels were the problems with implementing the allotment plan: the farmers shifted to producing commodities not covered by the plan (from corn to other feed crops) so that the total production did not decrease to intended level. See Shepherd (1942:598).

Note 6. The latter point does not negate the substantial leadership exercised by $\mathrm{H}$. Hoover to introduce and keep his farm relief program. However, it concerned specific policy details, rather than injecting any new ideas or frames. This leadership is also argued to be a manifestation of Hoover's peculiar political style - inability to maintain dialogue with other branches of the government, distrust in political partisanship and reliance on scientifically organized bureaucracy and mass-media proselytizing. Note, voluntary cooperation was an old and well-known idea preached by both "populist" agrarians, such as Grange, and by "official" Progressivists. See Fausold (1977).

Note 7. The Midwestern "agrarian" faction included such actors as H. A. Wallace (Secretary of Agriculture, and US Vice-President), M. L. Wilson (Under-Secretary of Agriculture). The urban "liberal" faction included Tugwell R. G. (Assistant Secretary of Agriculture), F. C. Howe (AAA) and others. See Gilbert (2000).

Note 8. There were points of divergence on the last point. Agrarians (particularly Wilson) preferred the direct participation of farmers in planning and administering farm programs, whereas "liberals" wanted greater involvement of the benevolent bureaucrats. Both groups subscribed to democratic management of the agricultural sector; however, the agrarian vision of "grass-roots" democracy clashed with "liberal" ideal of the democratically accountable state. See Summers (2000: 242).

Note 9. The Brannan plan (named after Secretary of Agriculture in H. Truman Administration) intended to achieve fairness objectives by reorienting policy away from price supports towards subsidization of the sector through a system of deficiency payments, compensating the difference between parity price and actual price received by farmer. This parity income system, in contrast to the New Deal parity price system, would reduce policy bias towards large scale producers. 